\title{
ANION-EXCHANGE RESIN-BASED DESULFURIZATION PROCESS
}

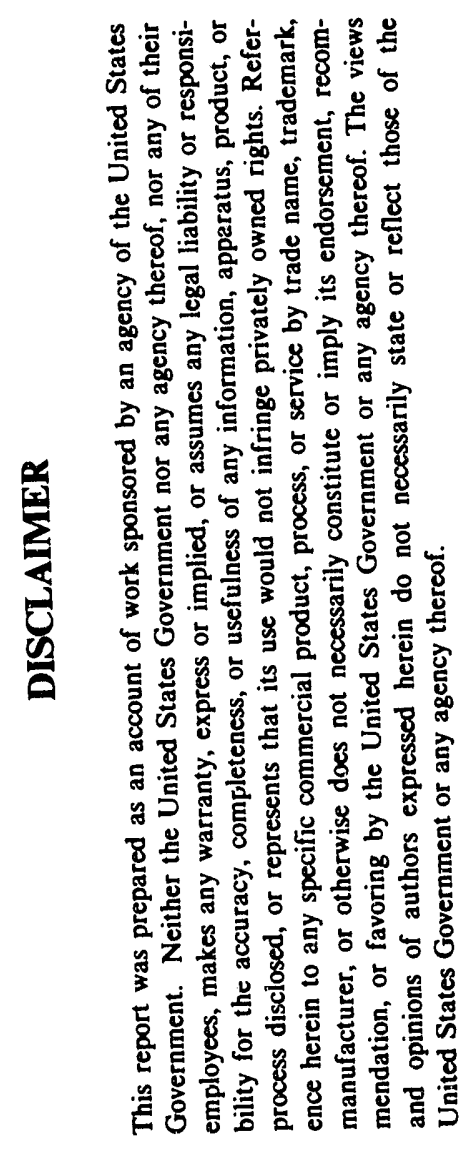

\author{
Quarterly Technical Progress Report
}

October 1, 1992 - December 31, 1992

Prepared by:

Atul C. Sheth

Rajeev Dharmapurikar

The University of Tennessee Space Institute

B.H. Goethert Parkway

Tullahoma, Tennessee $37388-8897$

DOE Grant No. DE-FG22-90PC90309 


\section{Table of Contents}

Page

EXECUTIVE SUMMARY $\ldots \ldots \ldots \ldots \ldots \ldots \ldots \ldots \ldots \ldots \ldots \ldots \ldots \ldots$ iv

1.0 INTRODUCTION $\ldots \ldots \ldots \ldots \ldots \ldots \ldots \ldots \ldots \ldots \ldots \ldots \ldots \ldots \ldots \ldots \ldots \ldots$

2.0 OBJECtIVES AND PROJECT DESCRIPTION $\ldots \ldots \ldots \ldots \ldots \ldots, 2$

3.0 PROJECT STATUS/PROGRESS TO DATE $\ldots \ldots \ldots \ldots \ldots \ldots \ldots, 2$

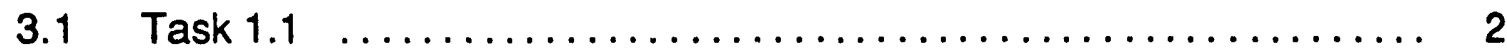

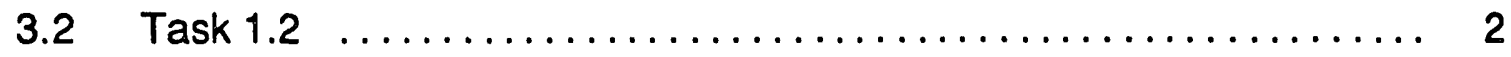

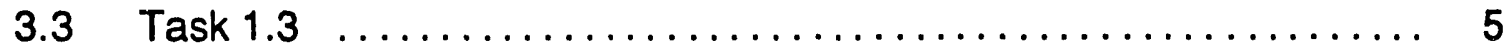

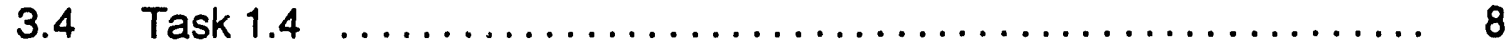

3.5 Task $1.5 \ldots \ldots \ldots \ldots \ldots \ldots \ldots \ldots \ldots \ldots \ldots \ldots \ldots \ldots \ldots, 8$

4.0 REfEREnCES $\ldots \ldots \ldots \ldots \ldots \ldots \ldots \ldots \ldots \ldots \ldots \ldots \ldots \ldots \ldots \ldots \ldots$ 


\section{List of Figures}

Page

Figure 1. Milestone Schedule and Status Report $\ldots \ldots \ldots \ldots \ldots \ldots \ldots . \ldots . \ldots$

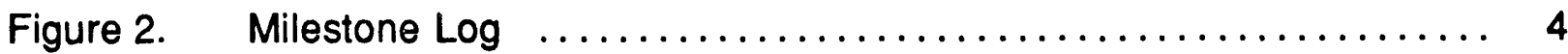

\section{List of Tables}

Page

Table 1. Performance Enhancement by Addition of Formic Acid

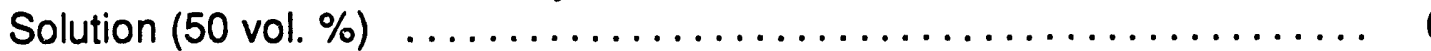

Table 2. Performance Enhancement by Addition of Acetic Acid Solution $(50 \mathrm{Vol} . \%)$................................ 7 


\section{EXECUTIVE SUMMARY}

Under DOE Grant No. DE-FG22-90PC90309, the University of Tennessee Space Institute (UTSI) is contracted to further develop its anion-exchange, resin-based desulfurization concept to desulfurize alkali metal sulfates. From environmental as well as economic viewpoints, it is necessary to remove soluble sulfates from the wastes created by flue gas desulfurization systems. In order to do this economically, a low-cost desulfurization process for spent sorbents is necessary. UTSI's anionexchange resin-based desulfurization concept is believed to satisfy these requirements.

During the reporting period, October 1, 1992 - December 31, 1992, UTSI has completed the batch mode experiments to evaluate the performance enhancement effect caused by organic acids on the resin's exhaustion efficiency. At present, batch mode experiments are being conducted to locate the position of the $\mathrm{CO}_{3}=$ and $\mathrm{SO}_{4}=$ ions in the affinity chart, and also reviewing/assessing the ASPEN Code's capabilities for use in the development of the Best Process Schematic and related economics.

Because of the past problems (now resolved) with the fixed-bed system, the addition of batch mode screening experiments and the Christmas holidays, the program is about 6-8 weeks behind schedule, but well within the budget. 


\subsection{INTRODUCTION}

Under the current grant (\# DE-FG22-90PC90309), the University of Tennessee Space Institute (UTSI) will perform the bench scale evaluation and further development of the anion-exchange resin-based desulfurization concept to desulfurize alkali metal sulfates. This concept has been developed and patented by UTSI under U.S. Patent No. $4,917,874$. The technical feasibility of this concept has been demonstrated and reported in the M.S. theses prepared by Butler(1) and Modeste(2). The developmental program proposed under this DOE grant includes screening of commercially available resins to select three candidate resins for further study. These three resins will undergo a series of experiments designed to test the resins' performance under different process conditions (including the use of spent MHD seed material). The best of these resins will be used in optimizing the regeneration step and in testing the effects of performance enhancers. The process schematic developed from the results will be used to estimate the related economics.

During this reporting period, October 1, 1992 to December 31, 1992, batch mode experiments to optimize the resin regeneration step as well as to evaluate the effect of potential performance enhancers (e.g. organic acids) were completed. Experiments in the batch mode are now proceeding to identify the location of the carbonate $\left(\mathrm{CO}_{3}=\right)$ ion in relation to the sulfate $\left(\mathrm{SO}_{4}=\right)$ ion in the affinity chart. Also, literature on the "ASPEN" computer code is being reviewed to become familiar with its capabilities. The ASPEN code will be used to develop the "Best Process Schematic" and the related process economics, if possible. 


\subsection{OBJECTIVES AND PROJECT DESCRIPTION}

Objectives to be satisfied as well as the detailed description of the project tasks and subtasks were described in the Quarterly Technical Progress Report for the period August 9, 1990 - December 31, 1990 (report no. DOE/PC/90309-1).

\subsection{PROJECT STATUS/PROGRESS TO DATE}

The progress made during the period October 1, 1992 - December 31, 1992 is indicated in Figures 1 and 2. Figure 1 shows the proposed schedule and the progress to date for each task. Figure 2 lists the major milestones to be accomplished under each task and their planned and actual completion dates. Activities carried out under each task are as follows:

\section{$3.1 \quad$ Task 1.1}

This task was completed in September 1991 and the results were reported in prior quarterly reports.

\subsection{Task 1.2}

This task was completed in August 1992 and the results were reported in the Annual Technical Progress Report for the period October 1, 1991 - September 30, 1992 (report no. DOE/PC/90309-8). If possible, the cycle efficiency of the selected three resins (IRA-68, -35 , and -93) using the identified optimum conditions for the resin regeneration step, will be evaluated under Task 1.3. 


\section{$3.3 \quad$ Task 1.3}

Batch mode experiments were performed to optimize the resin regeneration step. In these experiments, the effects of ammonia concentration, resin-to-solution ratio and mixing time were evaluated. Results from these experiments have been reported in earlier reports (e.g. report no. DOE/PC/90309-2 and -8).

The effect of performance enhancers (e.g. organic acids) on the exhaustion efficiency of the candidate resins was evaluated using small amounts of acetic acid and formic acid solutions of approximately $50 \mathrm{vol} \%$ strength. A significant improvement in the candidate resin's exhaustion efficiency was observed as the dosage of the organic acid solution was increased. The results are presented in Tables 1 and 2. From comparison of the results in Tables 1 and 2, it is evident that the acetic acid solution is more effective (especially at higher dosages) than the formic acid solution. According to the resin manufacturers, the weak-base, anion-exchange resins are recommended for use in the medium $\mathrm{pH}$ of $\leq 7.0$. However, although the starting $\mathrm{pH}$ of $\mathrm{K}_{2} \mathrm{SO}_{4}$ solution is 7.0 , as more and more ion-exchange takes place, more and more $\mathrm{HCO}_{3}$ - ions accumulate in the bulk solution. Because $\mathrm{HCO}_{3}$ - ions produce alkakine solution with $\mathrm{pH}$ ranging from $8.5-10$, the solution containing mixture of $\mathrm{SO}_{4}=$ and $\mathrm{HCO}_{3}$ - ions does not remain neutral. As a result, the exhaustion efficiency may be slightly reduced. By adding mild organic acids (such as acetic acid or formic acid), the initial solution pH is kept below 7.0 (probably around 4.5), and with further addition of the $\mathrm{HCO}_{3}$ - ions (as a result of the ion-exchange), the overall $\mathrm{pH}$ of the bulk solution containing the mixture of the $\mathrm{SO}_{4}=$ and $\mathrm{HCO}_{3}$ - ions still remains below or at $\mathrm{pH}=7.0$. 
As a result, the resin's exhaustion efficiency improves significantly. Thus, the organic acids most likely are behaving more like a pH buffering agent.

\section{Table 1. Performance Enhancement by Addition of Formic Acid Solution (50 vol. \%)}

Basis: - $5 \mathrm{wt} \% \mathrm{~K}_{2} \mathrm{SO}_{4}$ solution

- Batch size of resin $=50 \mathrm{ml}$.

- Mixing time $=30 \mathrm{~min}$.

- Resin-to-Solution ratio $=1: 2$

Resin

Iype

IRA-35

IRA-93

IRA-68

\section{Amount of added

$$
\text { acid solution }
$$ \\ (m/100 ml resin)}

0

2

4

6

8

0

2

4

6

8

0

2

4

6

8
$\% \mathrm{SO}_{4}{ }^{2-}$ Removed

during Exhaustion

51.1

57.3

62.1

62.6

64.1

50.0

55.3

54.5

56.6

59.6

53.6

56.5

57.5

59.8

67.9
$\%$ Improvement

12.0

21.5

22.6

25.4

10.6

8.0

13.1

19.2

5.3

7.3

11.5

26.6 
Table 2. Performance Enhancement by Addition of Acetic Acid Solution (50 Vol. \%)

Basis: $-5 \mathrm{wt} \% \mathrm{~K}_{2} \mathrm{SO}_{4}$ solution

- Batch size of resin $=50 \mathrm{ml}$.

- Mixing time $=30 \mathrm{~min}$.

- Resin-to-Solution ratio $=1: 2$

Resin

Amount of added

Iype acid solution ( $\mathrm{m} / 100 \mathrm{ml}$ resin)

$\% \mathrm{SO}_{4}{ }^{2-}$ - Removed during Exhaustion

$\%$ Improvement

IRA-35

0
2
4
6
8

51.2

52.6

55.8

58.1

67.0

2.3

9.3

13.7

8

50.0

IRA-93

0

50.0

$2 \quad 51.7$

$4 \quad 57.8$

6

62.2

31.3

8

70.4

3.3

15.7

24.4

40.9

IRA-68

0
2
4
6
8

53.6

63.5

65.7

18.4

70.6

22.5

6

72.9

At present, the batch mode experiments are also being performed to find the position of the carbonate ion $\left(\mathrm{CO}_{3}=\right)$ with respect to the sulfate ion $\left(\mathrm{SO}_{4}=\right)$ in the affinity chart. This determination is made by reacting the sulfate form of resin $\left(\mathrm{R}_{2} \cdot \mathrm{SO}_{4}\right)$ with $\mathrm{K}_{2} \mathrm{CO}_{3}$ solution of different strengths. The purpose of the experiments is to determine whether the sulfate form of resin can exchange with the carbonate ions in the solution. 
The results will determine whether only the $\mathrm{R} \cdot \mathrm{HCO}_{3}$ form of resin is useful or the $\mathrm{R}_{2} \cdot \mathrm{CO}_{3}$ form is also useful.

To date, the preliminary results have shown that for $\mathrm{K}_{2} \mathrm{CO}_{3}$ solutions of high concentrations ( $5 \mathrm{wt} \%$ or higher), some carbonate ions do exchange with the $\mathrm{SO}_{4}{ }^{2-}$ ions in the resin. However, at lower $\mathrm{K}_{2} \mathrm{CO}_{3}$ concentrations, the amount of $\mathrm{SO}_{4}{ }^{2-}$ ions removed from the resin is very small (or insignificant). This suggests that the position of the $\mathrm{CO}_{3}{ }^{2-}$ ion in the affinity chart should be very close to the $\mathrm{SO}_{4}{ }^{2-}$ ion. Because the preliminary results are still not conclusive, more experiments will be conducted.

\subsection{Task 1.4}

Development of the Best Process Schematic will involve the evaluations of the process parameters such as seed concentration, type of resin and regeneration characteristics. Chemical process engineering softwares such as ASPEN are being reviewed for their possible application to this particular use. Alternatively, developing a computer code specifically for this process is also under consideration.

\subsection{Task 1.5}

The following activities were completed under this task.

- The second annual technical progress report (report no. DOE/PC/90309-8) covering the periormance period from October 1, 1991 - September 30, 1992 was issued on October $27,1992$.

- The abstract entitled, "Spent Seed Regeneration in Coal-Fired MHD System Using Weak-Base, Anion-Exchange Resins," has been accepted for presentation and publication in the proceedings of the 5th International Conference 
on Processing and Utilization of Hlgh Sulfur Coals, to be held from October 24-28, 1993 in Lexington, Kentucky. The full technical paper is being prepared for peer review. This draft is due by February 15, 1993.

- Sterling Stevel's M.S. thesis which describes the work done in the first two years under the current DOE grant is now available for anyone's use from the UTK/UTSI libraries.

At the present time, the project is about $6-8$ weeks behind the original schedule (due to earlier equipment related problems (now resolved), increase in work scope due to additional batch mode screening and the Christmas holidays). However, it is well within the budget.

\subsection{REFERENCES}

1. Butler, W.A., "Bench Scale Evaluation of Anion-Exchange Resin-Based Seed Regeneration Concept for Coal-Fired Magnetohydrodynamics Power System," a thesis presented for M.S. degree, The University of Tennessee Space Institute, December 1986.

2. Modeste, D.C., "Evaluation of Improved Anion-Exchange Resin-Based Seed Regeneration Concept for Coal-Fired MHD Power System," a thesis presented for M.S. degree, The University of Tennessee Space Institute, December 1988.

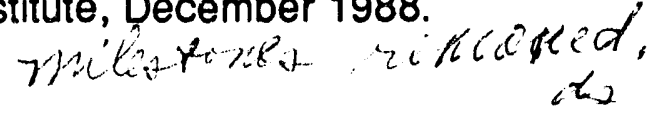


